\title{
Do Gonadotropins Influence Serum Lipoprotein(a) Concentrations? Observations on Children, Adolescents and Adults
}

\author{
Marianne Schumacher ${ }^{1}$, Siegfried Weigert ${ }^{2}$ and William Graham Wood ${ }^{1}$ \\ 1 Institut für Klinische Laboratoriumsdiagnostik \\ 2 Klinik für Kinder- und Jugendmedizin \\ Klinikum der Hansestadt Stralsund GmbH, Stralsund, Germany
}

\begin{abstract}
Summary: Data from 7045 subjects were examined. The main groups consisted of the following in- and outpatients: 1414 neonates, 2554 children and adolescents (1336 males, 1218 females), 1209 women directly postpartum, 786 non-pregnant women and 1090 men aged between 18 and 100 years of age. Unless otherwise stated, persons were under medical observation or therapy.
\end{abstract}

The results were obtained over a three-year period using an in-house immunoluminometric assay specific for apolipoprotein(a) using two polyclonal antibodies and a single lot of reagents to allow for comparability of results.

Girls aged between 10 and 12 years of age had significantly higher serum lipoprotein(a) (median $124 \mathrm{mg} / \mathrm{l})$ levels than boys (median $88 \mathrm{mg} / \mathrm{l}$ ) of the same age ( $p<0.05$ - Mann-Whitney U-test). Post-pubertal lipoprotein(a) concentrations were not significantly different from pre-pubertal levels. Between the ages of 0-9 and 13-17 years there were no statistically significant sex-linked differences in serum lipoprotein(a).

In adults, lipoprotein(a) serum levels were significantly higher in women (median $163 \mathrm{mg} / \mathrm{l}$ ) aged between 50 and 59 years, when compared with men (median $128 \mathrm{mg} / \mathrm{l})$ of the same age group $(\mathrm{p}=0.05-$ Kruskal-Wallis one way ANOVA followed by the Nemenyi test).

There was no significant difference in serum lipoprotein(a) concentrations between healthy women (median 91 $\mathrm{mg} / \mathrm{l}$ ), women direct postpartum (median $116 \mathrm{mg} / \mathrm{l}$ ) and in-patient women (median $117 \mathrm{mg} / \mathrm{l}$ ) aged between 18 and 41 years of age $(p=0.11-0.96)$. There was no correlation between maternal lipoprotein(a) and birth weight in mature newborns $(\mathrm{r}=-0.028-0.085)$.

The results may indicate a direct influence of gonadotropins at puberty and during the menopause which cause an increase in serum lipoprotein(a) concentrations.

\section{Introduction}

Although lipoprotein(a) is an accepted additional and independent risk factor for early onset atherosclerotic changes $(1-4)$, relatively little is known about factors influencing its concentration in blood. Conflicting reports about changes in lipoprotein(a) concentrations in serum in response to hormonal activity may be due to several conditions, including the size of the group studied $(5,6)$, the time-period of observation $(6,7)$, the method used for quantitation (8), and the statistics used for comparison (9).

The non-Gaussian distribution of lipoprotein(a) concentrations, together with the wide range of concentrations found in serum, allow only non-parametric statistics to be used. In addition, the median value for lipoprotein(a) lies in a concentration range where relative few results are to be found, in contrast to the mean value in a normally distributed population. The consequence of this fact is that large numbers of observations within a group are needed to obtain a stable median lipoprotein(a) concentration.

The results presented in this article have been derived from over three years of observations using a single lot of reagents, thus excluding variation due to methodology and changing reagents and calibration materials.

The hypothesis that lipoprotein(a) concentrations may be affected by gonadotropins has been examined using observations made in this hospital as well as from those published in the literature, where the effects of pregnancy $(7,10-14)$, pituitary hormones $(15,16)$ and different drugs $(11,17-19)$ are well documented.

\section{Subjects and Methods}

Data from a total of 7045 subjects (3159 males, 3886 females) were processed in this study and included 2554 children and adolescents (1336 males, 1218 females), 1209 mothers directly post- 


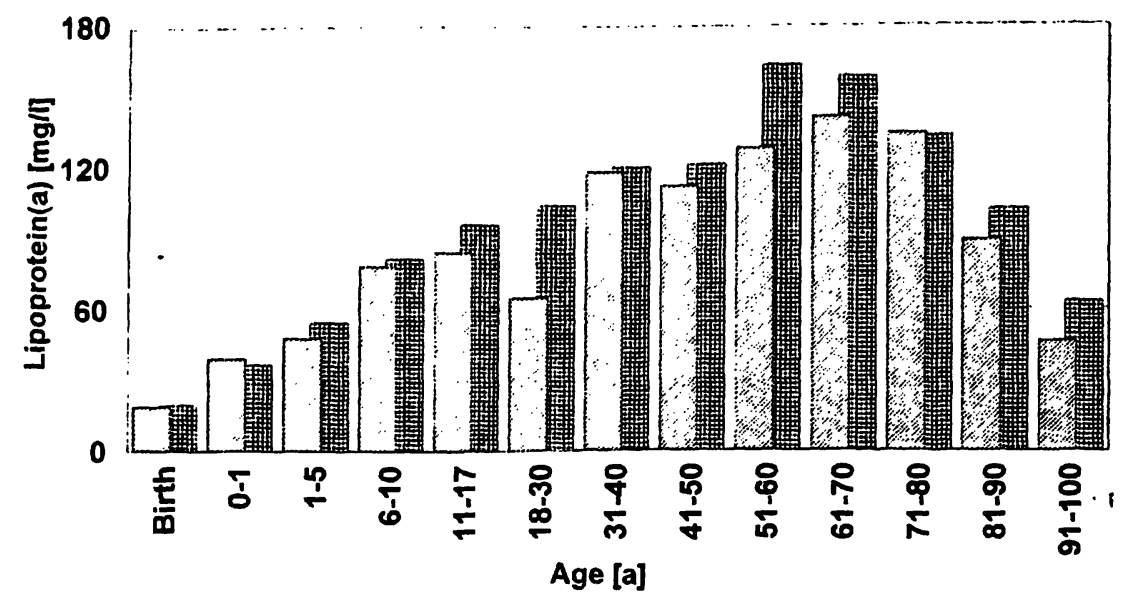

Fig. 1 Median lipoprotein(a) concentrations in subjects at birth and aged between 2 weeks and 100 years of age. Data from 3159 males $\mathbb{Z}$ and 3886 females were used.

partum and 786 non-pregnant women aged between 18 and 96 years of age. In addition, data from 1090 males aged between 18 and 100 years of age and 1414 newborns were used for comparison. Lipoprotein(a) was measured with an in-house immunoluminometric assay using two polyclonal antibodies directed against apolipoprotein(a). The method has been published elsewhere (20) and has been used for extensive studies $(21-23)$ as well as for routine purposes. A single lot of reagents has been used throughout the study and thus allows for comparison of results over the whole observation period.

\section{Statistics}

Non-parametric statistics have been used throughout. The median has been used as the measure of central tendency, relevant percentiles as measure of dispersion. For comparison of two groups, the Mann-Whitney U-test was used for independent samples; for comparison of several groups, the Kruskal-Wallis one way analysis of variance was followed by the Nemenyi test to check for differences between groups.

\section{Results}

Figure 1 shows the distribution of lipoprotein(a) values throughout life in 7045 subjects. Table la shows the same for children aged 2 weeks to 17 years. Table $1 \mathrm{~b}$ also shows the detailed data for women aged 18-59 years, who have been depicted in figure 1 . Table 2 shows the correlation between maternal serum lipoprotein(a) and birth weight for all mother child pairs, and for mother child pairs where maternal lipoprotein(a) was in excess of $300 \mathrm{mg} / \mathrm{l}(300-3150 \mathrm{mg} / \mathrm{l})$. Data are sorted according to sex of the child.

From figure 1 and table $1 \mathrm{a}$ it can be clearly seen that lipoprotein(a) peaks occur in females at puberty (tab. $1 \mathrm{a})$ and after the menopause (fig. 1). In girls aged between 10 and 12 years of age, lipoprotein(a) concentrations are significantly higher $(p<0.05)$ than in boys of the corresponding ages. Between the ages of 0 and 9, and 13 and 17 years of age, no statistically significant sex-linked difference in lipoprotein(a) levels was found. In adults, lipoprotein(a) was significantly higher in women aged 50 to 59 years of age $(p=0.05)$ than in men of the corresponding age group.
Table $1 \mathrm{~b}$ shows the lipoprotein values in age matched females, for healthy hospital staff attending a routine check-up, for non-selected in-patient women and for women directly after the birth of a child. Although the median values are different, these are not significant (healthy women vs hospitalised women $\mathrm{p}=0.45$, healthy women vs postpartal women $p=0.11$, hospitalised

Tab. 1a Median lipoprotein(a) concentrations in serum of children aged 2 weeks to 17 years of age divided into age and sex. Median concentrations are given in $\mathrm{mg} / \mathrm{l}$.

\begin{tabular}{|c|c|c|c|c|}
\hline \multirow{2}{*}{$\begin{array}{l}\text { Age } \\
\text { group } \\
\text { (years) }\end{array}$} & \multicolumn{2}{|c|}{ Male children } & \multicolumn{2}{|c|}{ Female children } \\
\hline & $\begin{array}{l}\text { Lipo- } \\
\text { protein(a) } \\
(\mathrm{mg} / \mathrm{l})\end{array}$ & $\mathrm{n}$ & $\begin{array}{l}\text { Lipo- } \\
\text { protein(a) } \\
(\mathrm{mg} / \mathrm{l})\end{array}$ & $\mathrm{n}$ \\
\hline 2 weeks -1 year & 38.9 & 167 & 36.4 & 161 \\
\hline 1 & 30.8 & 97 & 41.7 & 96 \\
\hline 2 & 45.5 & 97 & 44.7 & 80 \\
\hline 3 & 53.0 & 76 & 44.7 & 55 \\
\hline 4 & 61.5 & 83 & 68.6 & 56 \\
\hline 5 & 59.0 & 81 & 80.5 & 71 \\
\hline 6 & 80.2 & 104 & 79.8 & 57 \\
\hline 7 & 75.7 & 76 & 92.7 & 59 \\
\hline 8 & 69.5 & 64 & 76.3 & 82 \\
\hline 9 & 76.7 & 62 & 73.8 & 73 \\
\hline 10 & 97.4 & 86 & 118 & 76 \\
\hline 11 & 88.2 & 66 & 146 & 60 \\
\hline 12 & 79.4 & 60 & 93.0 & 71 \\
\hline 13 & 74.1 & 69 & 83.9 & 60 \\
\hline 14 & 103 & 51 & 73.0 & 53 \\
\hline 15 & 117 & 34 & 102 & 44 \\
\hline 16 & 74.3 & 40 & 95.0 & 39 \\
\hline 17 & 66.9 & 19 & 101 & 30 \\
\hline $1-5$ years & 47.5 & 434 & 54.0 & 358 \\
\hline $6-10$ & 78.1 & 396 & 81.4 & 342 \\
\hline $11-17$ & 84.3 & 339 & 95.8 & 357 \\
\hline All & 66.5 & 1336 & 67.6 & 1218 \\
\hline
\end{tabular}

The corresponding mean values for all subjects was $175 \mathrm{mg} / \mathrm{l}$ (boys $167 \mathrm{mg} / \mathrm{l}$, girls $183 \mathrm{mg} / \mathrm{l}$ ) showing the extreme skewness of the data (mean: median $=2.61$ ). The median value stabilises first after the number of subjects in a group exceeds at least 100 persons, and so groups from children aged between 1 and 17 years were constructed as in the lower part of the table. Only the group values were used in figure 1. 
Tab. 1b Lipoprotein(a) data for healthy, postpartum and sick females aged 18-59 years of age.

Median concentrations are given in $\mathrm{mg} / \mathrm{l}$.

\begin{tabular}{|c|c|c|c|c|c|c|}
\hline \multirow{2}{*}{$\begin{array}{l}\text { Age group } \\
\text { (years) }\end{array}$} & \multicolumn{2}{|l|}{ Healthy } & \multicolumn{2}{|l|}{ Postpartum } & \multicolumn{2}{|l|}{ Sick } \\
\hline & $\begin{array}{l}\text { Lipoprotein(a) } \\
\text { (mg/l) }\end{array}$ & $n$ & $\begin{array}{l}\text { Lipoprotein(a) } \\
(\mathrm{mg} / \mathrm{l})\end{array}$ & $\mathrm{n}$ & $\begin{array}{l}\text { Lipoprotein(a) } \\
\text { (mg/l) }\end{array}$ & $\mathrm{n}$ \\
\hline $\begin{array}{l}18-29 \\
30-39 \\
40-49 \\
50-59\end{array}$ & $\begin{array}{r}87.0 \\
87.5 \\
97.0 \\
146\end{array}$ & $\begin{array}{r}104 \\
112 \\
55 \\
93\end{array}$ & $\begin{array}{l}111 \\
121 \\
a\end{array}$ & $\begin{array}{l}876 \\
320\end{array}$ & $\begin{array}{l}79.5 \\
121 \\
130 \\
190\end{array}$ & $\begin{array}{r}56 \\
54 \\
56 \\
110\end{array}$ \\
\hline
\end{tabular}

a As there were only 13 mothers over 40 years of age, these were not included in the table.

The median lipoprotein(a) concentration of this group was $184 \mathrm{mg} / \mathrm{l}$.

women vs post partal women $\mathrm{p}=0.96$ ), thus allowing all women of a given age-group to be included in one group in figure 1.

Table 2 shows that there was no correlation between maternal serum lipoprotein(a) and birth weight in full term babies (38th-43rd week of pregnancy). This was true before and after logarithmic transformation of lipoprotein(a) concentrations. The correlation between postpartal maternal and neonatal lipoprotein(a) concentrations after logarithmic transformation was $r=0.592$ $(n=1209)$.

Relevant assay data, represented by the mean and interassay coefficient of variation (in parentheses) for four control sera were as follows:

Serum A: mean $105 \mathrm{mg} / \mathrm{l}(5.66 \%) \mathrm{n}=172$,

Serum B: mean $377 \mathrm{mg} / \mathrm{l}(5.55 \%) \mathrm{n}=62$,

Serum C: mean $808 \mathrm{mg} / \mathrm{l}(4.30 \%)$

[declared content $800 \mathrm{mg} / \mathrm{l}$ ] $\mathrm{n}=31$ and

Serum D: mean $37.4 \mathrm{mg} / \mathrm{l}(7.86 \%) \mathrm{n}=61$.

\section{Discussion}

Many conflicting reports have been published on the behaviour of lipids and lipoproteins during puberty (24),

Tab. 2 Correlation between maternal lipoprotein(a) and birth weight according to sex of the baby and lipoprotein(a) concentration of the mother at birth. Only full-term newborns are included.

\begin{tabular}{llll}
\hline & $\mathrm{n}$ & $\begin{array}{l}\text { Linear } \\
\text { correlation }\end{array}$ & $\begin{array}{l}\text { Log } \\
\text { correlation }\end{array}$ \\
\hline $\begin{array}{l}\text { Lipoprotein(a) } \\
\text { less than } 300 \mathrm{mig} / \mathrm{l}\end{array}$ & & & \\
Male offspring & 420 & -0.014 & 0.020 \\
Female offspring & 367 & 0.007 & -0.028 \\
& & & \\
Lipoprotein(a) & & & \\
above 300 mg/l & & & \\
Male offspring & 137 & -0.018 & 0.035 \\
Female offspring & 150 & 0.085 & 0.033 \\
\hline
\end{tabular}

The data for the linear correlation was calculated from the birth weight $(x)$ and the lipoprotein(a) concentration in $\mathrm{mg} / \mathrm{l}(\mathrm{y})$.

The data for the logarithmic correlation was calculated from the birth weight $(x)$ and the decadian logarithm of the lipoprotein(a) concentration $(y)$. pregnancy $(7,10-14)$, under the influence of drugs $(19$, $25)$, oral contraceptives (17) and hormones $(19,26,27)$, including gonadotropins $(15,16)$. Results from animal studies (28) cannot be compared directly with results from humans (5) without due consideration of animal physiology. Other results come from studies in which the number of subjects is too small for comparison (5), even when 'statistically significant' differences have been found.

Reports of behavour of lipoprotein(a) during pregnancy are also conflicting, some authors not seeing an increase $(10,12,29)$, others reporting significant increases (11, $13,14)$. In a study of smoking and non-smoking pregnant women, van Wersch et al. (30) showed that the lipoprotein(a) levels in non-smoking pregnant women were on average twice as high as in women who smoked, the latter having the same concentrations as non-pregnant women.

Association of high levels of lipoprotein(a) in maternal serum have been associated with severe pre-eclamptic pregnancy (31) and foetal growth retardation due to insufficient placental circulation (32). Peripartal reductions in total cholesterol, high density lipoprotein cholesterol and apolipoprotein A-I, when compared with levels in the 35th week of pregnancy have also been published (5), as have observations in reduction of triacylglycerols, cholesterol and apolipoprotein B measured 6 weeks postpartum, when compared with levels in the 35 th and 36th weeks of pregnancy $(10,12)$. Chiang and co-workers (12), however reported no change in apolipoprotein A-I during pregnancy.

In a study covering 232 women during pregnancy ( 114 Caucasians, 118 Africans/Afro-Caribbeans), Koukou et al. (6) found lower levels of total cholesterol, low-density lipoprotein cholesterol, triacylglycerols and apolipoprotein B, but higher levels of high-density lipoprotein cholesterol and lipoprotein(a) in Africans/Afro-Caribbeans, when compared with Caucasians. The differences were not due to weight, age, parity or post-load plasma glucose levels.

Muñoz et al. (33) have observed decreased apolipoprotein $\mathrm{A}$ and triacylglycerols in pregnancies with intra-uter- 
ine growth retardation. Rheological changes were seen in this group of patients which were due to the inhibition of fibrinolysis by increased levels of apolipoprotein B.

Zecliner and co-workers (7) reported a steady increase of lipoprotein(a) in pregnant women up until the 19th week, where the values were on average 2.8 times higher than before the pregnancy, after which values fell to pre-pregnant values at birth. Apolipoprotein B and total cholesterol increased during pregnancy, the time courses being independent of that of lipoprotein(a).

Soma et al. (11) reported that steroid sex-hormones were capable of reducing lipoprotein(a) concentrations in postmenopausal women, and after cessation of hormone-substitution, that the levels returned to pre-treatment concentrations. In men undergoing orchidectomy for prostatic cancer, the same workers observed increases in lipoprotein(a) of $20 \%$, whereas treatment with oestrogens resulted in a reduction of lipoprotein(a) by $50 \%$. Similar results have been reported by Habiba et al. (34). In hormone replacement therapy using a combination of oestriol, oestrone, oestradiol and norethisterone a reduction of serum lipoprotein(a) concentrations and protein-S activity was seen over the observation period of one year.

Radwanska (18) has presented data in a review article which implies different effects of sex-steroids and synthetic oestrogens on lipoprotein levels, and that these effects differ with age, sex, pregnancy, body weight and smoking habits. Moreover, the route of application and whether the hormones are endogenous or exogenous appear to influence lipoprotein levels, thus complicating the picture. Similar results have recently been published by Stone (19).

Results from the Burgos study on high density lipoproteins during the second decade of life (24) noted increases in high density lipoprotein phospholipids in girls after puberty, but not in boys. In another Spanish study girls and boys between 13-14 years of age from Alcoy (35), $38 \%$ were classified as having elevated lipoprotein(a) and were classified as 'at-risk'. Further comparisons with values obtained in our observations were not possible, due to the use of parametric statistics.

In the Atherosclerosis Risk in Communities (ARIC) study (36) carried out on men and women aged between 45-64 years of age, women, both black and white, had higher lipoprotein(a) levels than men. In addition, in postmenopausal women on hormone replacement therapy lipoprotein(a) as well as apolipoprotein B and low density lipoprotein cholesterol levels were lower than in non-replacement women.

Stevenson et al. (37) conclude from a study on the influence of age and menopause on serum lipids and lipoproteins, that 'the menopause is associated with potentially adverse changes in lipids and lipoproteins, independent of any effects of aging. These changes may in part explain the increased incidence of coronary heart disease seen in postmenopausal women'.

The observations made by different groups must first be classified exactly before attempting to extract data for support of the hypothesis that gonadotropins directly influence levels of lipoprotein(a) in serum.

The results from the Burgos study (24) show that changes in the phospholipid content of high-density lipoproteins only occured in girls during and after puberty. In our study, significant increases in serum lipoprotein(a) occured in girls during puberty, but decreased afterwards.

In postmenopausal women several groups (34-37) have reported changes in lipid and lipoprotein profiles, including an increase in lipoprotein(a), which can be reversed by sex-steroid therapy. The review of Radwanska (18) has shown that certain sex-steroids are capable of changing the lipid and lipoprotein levels, including the reduction of lipoprotein(a). From our data, there is a significant increase in lipoprotein(a) after the menopause, which is seen until the end of the eighth decade of life.

The Austrian group of Zechner et al. (7) observed increases in lipoprotein(a) during the first half of pregnancy, values then returning to normal at birth. Other cholesterol fractions increased well into the second half of pregnancy. The first half of pregnancy is 'governed' by gonadotropins, the second by sex-steroids.

The above results show that gonadotropins increase lipoprotein(a), as seen in the results from pubertal girls, but not boys, and in postmenopausal women, but not in agematched men. Reduction of post-menopausal gonadotropins by steroid sex-hormones results in a fall in serum lipoprotein(a). The different time courses of different lipids and lipoprotein fractions during pregnancy and after the menopause point to an independent pathway for lipoprotein(a), and which may very well support the observations and theory of Stevenson et al. (37).

The peak of lipoprotein(a) levels at puberty in girls may reflect the gonadotropin activity, the reduction after puberty to the interaction between gonadotropins and sexsteroids during the menstrual cycle.

The results from the postmenopausal women can only support a hormone replacement therapy to reduce the increased risk of cardiovascular problems in this group.

From our results and those from other groups we may infer that an increase in gonadotropins may contribute to an adverse effect, namely an increase, in lipoprotein(a), which may be reversed by sex-hormone steroid substitu- 
tion. From the results from oestrogen therapy on orchidectomised men (11), the lowering of lipoprotein(a) is not sex-linked. Further indirect evidence for a link between gonadotropins and lipoprotein(a) may be seen in the fact that long-term hormone replacement therapy in postmenopausal women reduces the incidence of myocardial infarction by up to $50 \%$ during the therapeutical period (38). After cessation of therapy there is less consensus as to whether this protective effect is retained.

\section{References}

1. Scanu AM. $L p(a)$ as a marker of coronary heart disease. Clin Cardiol 1991; 14:44-9.

2. Utermann G. Lipoprotein (a): a genetic factor for premature coronary heart disease. Curr Opin Lipidol 1990; 1:404-10.

3. Sandkamp M, Funke H, Schulte $H$, Köhler E, Assmann G. Lipoprotein (a) is an independent risk factor for myocardial infarction at a young age. Clin Chem 1990; 36:20-3.

4. Kostner GM, Avogaro P, Cazzolato G, Marth E, Bittolo-Bon G, Quinci GB. Lipoprotein (a) and the risk of myocardial infarction. Atherosclerosis 1981; 38:51-61.

5. Del Priore G, Chatterton RT Jr, Chandarana A, Silver R. Comparison of maternal serum lipids before and during partition. Obstet Gynecol 1993; 82:837-40.

6. Koukkou E, Watts GF, Mazurkiewicz J, Lowy C. Ethnic differences in lipid and lipoprotein metabolism in pregnant women of African and Caucasian origin. J Clin Pathol 1994; 47:1105-7.

7. Zechner R, Desoye G, Schweditsch MO, Pfeiffer KP, Kostner $\mathrm{GM}$. Fluctuations of plasma lipoprotein-A concentrations during pregnancy and post partum. Metabolism 1986; 35:333-6.

8. Berg K. Confounding results of $\mathrm{Lp}(\mathrm{a})$ lipoprotein measurements with some test kits. Clin Genet 1994; 46:57-62.

9. Bhatnagar D, Durrington PN. Does measurement of apolipoproteins add to the clinical diagnosis and management of dyslipidaemias? Curr Opin Lipidol 1993; 4:299-304.

10. Silliman K, Shore V, Forte TM. Hypertriglyceridemia during late pregnancy is associated with the formation of small dense low-density lipoproteins and the presence of large buoyant high-density lipoproteins. Metabolism 1994; 43:1035-41.

11. Soma MR, Meschia M, Bruschi F, Morrisett JD, Paoletti R, Fumagalli R, Crosignani P. Hormonal agents used in lowering lipoprotein(a). Chem Phys Lipids 1994; 67-68:345-50.

12. Chiang AN, Yang ML, Hung JH, Chou P, Shyn SK, Ng HT. Alterations of serum lipid levels and their biological relevances during and after pregnancy. Life Sci 1995; 56:2367-75.

13. Neary RH, Kilby MD, Kumpatula P, Game FL, Bhatnagar D, Durrington PN, O'Brien PM. Fetal and maternal lipoprotein metabolism in human pregnancy. Clin Sci Colch 1995; 88:311-8.

14. Bartens W, Wanner C. Lipoprotein(a): new insights into an atherogenic lipoprotein. Clin Invest 1994; 72:448-67.

15. Conrad J, Badevant A, Thomas JL, Ochsenbein E, Denis C, Guyene TT, Degrelle H. Cardiovascular risk factors and combined estrogen-progestin replacement therapy: a placebo-controlled study with nomegestrol acetate and estradiol. Fertil Steril 1995; 64:957-62.

16. Morishima A, Grumbach MM, Simpson ER, Fisher C, Qin K. Aromatase deficiency in male and female siblings caused by a novel mutation and the physiological role of estrogens. J Clin Endocrinol Metab 1995; 80:3689-98.

17. Krauss RM, Burkman RT Jr. The metabolic impact of oral contraceptives. Am J Ostet Gynecol 1992; 167:1177-84.

18. Radwanska $\mathrm{E}$. The role of reproductive hormones in vascular disease and hypertension. Steroids 1993; 58:605-10.

19. Stone NJ. Secondary causes of hyperlipidemia. Med Clin North Am 1994; 78:117-41.

20. Keßler A, Schumacher $M$, Wood WG. Immunoluminometric assays for the quantification of apolipoproteins A-I, B, C-II,
From the data in table $1 \mathrm{~b}$ there is no support to the claim that high maternal lipoprotein(a) levels were correlated with lower birth weight due to placental insufficiency $(31,32)$ at least in full-term babies.

An interesting postulation for future therapy is whether steroids with an aromatic A-ring may be 'designed' to reduce lipoprotein(a), without having the unwanted side effects, at least in men, of feminisation.

apolipoprotein(a) and lipoprotein(a). Eur J Clin Chem Clin Biochem 1994; 32:127-35.

21. Wood WG, Schumacher M, Weigert S. (Apo)lipoprotein(a) concentrations at birth and in the first days and months of life - studies on the distribution of serum levels and the predictive value of measurements made at this time. Eur $\mathrm{J}$ Clin Chem Clin Biochem 1995; 33:139-45.

22. Wood WG, Schumacher M. Lipoprotein(a) concentrations in non-selected hospitalised patients between 18 and 100 years of age: comparison with cholesterol fractions and triacylglycerols in patients with lipid-status requests. Eur $\mathrm{J}$ Clin Chem Clin Biochem 1995; 33:903-134.

23. Schumacher M, Keßler A, Bahlmann G, Wood WG. Acute changes of apolipoproteins A-I, B, C-II and lipoprotein(a) in serum covering the period from directly before to 48 hours after chronic haemodialysis. Eur $\mathrm{J}$ Clin Chem Clin Biochem 1994; 32:123-5.

24. Jover-Sans E, Vella-Ramirez JC. Colesterol y fosfolipidos en lipoproteinas de alta densidad y sus subfracciones en una poblacion an la segunda decada de la vida. An Esp Pediatr 1992; 37:493-8.

25. Maher VM, Brown BG, Marcovina SM, Hilliger LA, Zhao $\mathrm{XQ}$, Albers JJ. Effects of lowering elevated LDL cholesterol on the cardiovascular risk of lipoprotein(a). J Am Med Ass $1995 ; 1771-4$.

26. Kung AW, Pang RW, Janus ED. Elevated serum lipoprotein(a) in subclinical hypothyroidism. Clin Endocrinol Oxf 1995; 43:445-9.

27. Barbagallo CM, Averna MR, Liotta A, La Grutta S, Maggio C, Casimiro L, et al. Plasma levels of lipoproteins and apolipoproteins in congenital hypothyroidism: effects of L-thyroxine substitution therapy. Metabolism 1995; 44:1283-7.

28. Watson TD, Burns L, Packard CJ, Shepherd J. Effects of pregnancy and lactation on plasma lipid and lipoprotein concentrations, lipoprotein composition and post-heparin lipase activities in Shetland pony mares. J Reprod Fertil 1993; 97:563-8.

29. Mazurkiewicz JC, Watts GF, Warburton FG, Slavin BM, Lowy C, Koukkou E. Serum lipids, lipoproteins and apolipoproteins in pregnant non-diabetic patients. J Clin Pathol 1994; 47:728-31.

30. Wersch JW, van-Mackelenbergh BA, Ubachs JM. Lipoprotein(a) in smoking and non-smoking pregnant women. Scand $\mathrm{J}$ Clin Invest 1994; 54:361-4.

31. Meekins JW, Pijnenborg R, Hanssens $M$, van-Assche $A$, McFayden IR. Immunohistochemical detection of lipoprotein(a) in the wall of placental bed spiral arteries in normal and severe preeclamptic pregnancies. Placenta 1994; 15:511-24.

32. Berg $K$, Roald $B$, Sande $H$. High $L p(a)$ lipoprotein level in maternal serum may interfere with placental circulation and cause fetal growth retardation. Clin Genet 1994; 46:52-6.

33. Muñoz A, Uberos J, Molina A, Valenzuela A, Cano D, Ruiz C, Molina-Font JA. Relationship of blood rheology lipoprotein profile during normal pregnancies and those with intrauterine growth retardation. J Clin Pathol 1995; 48:571-4.

34. Habiba M, Akkad A, al-Azzawi F. Effect of a new cyclical sequential postmenopausal HRT on lipoprotein, apoprotein and thrombophilia profile. Eur J Obstet Gynecol Reprod Biol 1995; 62:89-94. 
35. Arenas-Jimenez JJ, Quillez-Ivorra C, Sastre-Pascual JF, Arenas-Adarve M, Sevadilla-Soler L, Roca-Villanueva B, SeguiMolto R. Niveles de lipoprotein (a), otros lipidos y lipoproteinas en adolescentes del area sanitaria de Alcoy. An Med Interna 1993; 10:9-15.

36. Brown SA, Hutchinson R, Morrisett J, Boerwinkle E, Davis CE, Gotto AM Jr, Patsch W. Plasma lipid, lipoprotein cholesterol, and apoprotein distributions in selected US communities. The Atherosclerosis Risk in Communities (ARIC) Study. Arterioscler Thromb 1993; 13:1139-58.

37. Stevenson JC, Crook D, Godsland IF. Influence of age and menopause on serum lipids and lipoproteins in healthy women. Atherosclerosis 1993; 98:83-90.
38. Weiss NS. Health consequence of short- and long-term postmenopausal hormone therapy. Clin Chem 1996; 42:1342-4.

Received June 24/September 9, 1996

Corresponding author: Professor Dr. William Graham Wood, Institut für Klinische Laboratoriumsdiagnostik, Klinikum der Hansestadt Stralsund, KKH am Sund, Postfach 23 41, D-18410 Stralsund, Germany 